\title{
STABILITY OF AN ELLIPSOIDAL HEAD WITH A CENTRAL NOZZLE UNDER AXIAL LOAD
}

\author{
P. JASION ${ }^{1}$, K. MAGNUCKI ${ }^{2}$
}

\begin{abstract}
The subject of the numerical investigation is an ellipsoidal head with a central (axis-symmetrical) nozzle. The nozzle is loaded by axial load force. The ellipsoidal head is under axial-symmetrical compression load. The numerical FEM model is elaborated. The calculation will provide the critical loads and equilibrium paths for the sample head.. The investigation will measure the influence of the diameter of the nozzle on the critical state of the ellipsoidal head.
\end{abstract}

Keywords: ellipsoidal head, stability, buckling, pressure vessel

\section{INTRODUCTION}

Pressure tanks provided with nozzles are usually essential for petrochemical systems. The nozzles are subject to certain loads. A comprehensive description of many problems related to strength, stability and structure of metal vessels designed for liquids and gases is presented by Ziółko [11]. The theoretical fundamentals of shell stability and the methods of calculating the critical loads are described in many monographs, e.g. Bushnell [2], Григолюк and Кабанов [5], Thompson and Hunt [9] and Tovstik and Smirnov [10]. The problems of strength and stability of dished heads of pressure vessels have been researched for many years and are described in review papers such as: Błachut and Magnucki [1] and Krivoshapko [8]. Internal or external pressure is a basic load in studying the vessel buckling - shells of revolution, e.g. Jasion [7]. In the case of vessel structures other load types also occur in practice, i.e. local loads.

\footnotetext{
${ }^{1} \mathrm{PhD}$, Institute of Applied Mechanics, Poznan University of Technology, Poznan, Poland; pawel.jasion@put.poznan.pl, corresponding author

${ }^{2}$ Professor, Institute of Applied Mechanics, Poznan University of Technology, Poznan, Poland;

krzysztof.magnucki@put.poznan.pl
} 
Theoretical research of spherical shells buckling under such load types are presented e.g. in Fitch [4], Gupta et al. [6] and Evkin [3].

This paper is devoted to an ellipsoidal head with a central nozzle (Fig. 1). The nozzle is loaded with an axial force. Hence, the ellipsoidal head is subject to the axially symmetric load. In the linear buckling analysis the relation between the diameter of the nozzle and the buckling load and buckling shape is analyzed. The results of non-linear analysis show the post-critical behavior of the head.

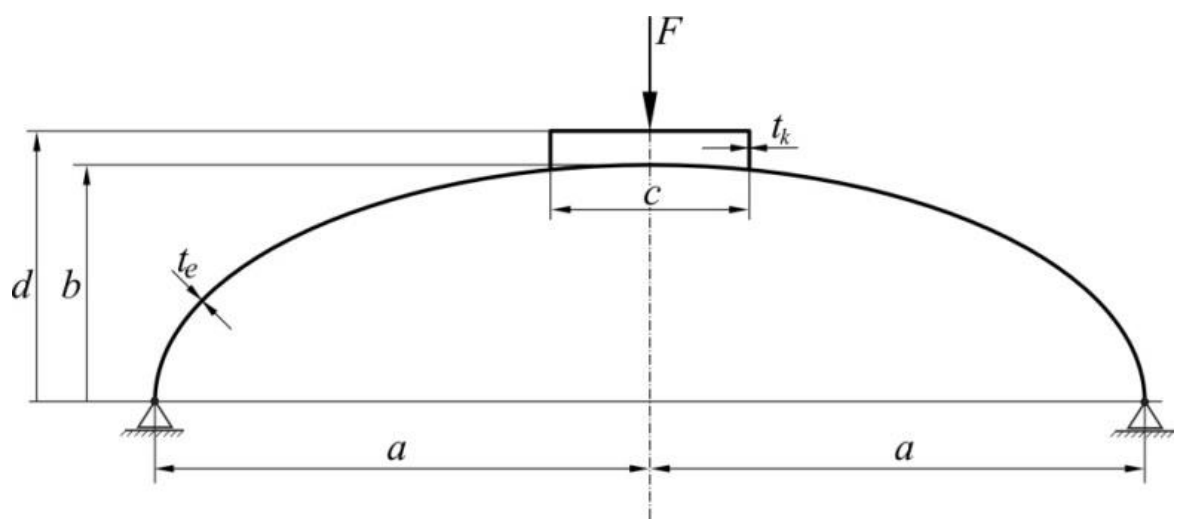

Fig. 1. Scheme of the ellipsoidal head with a nozzle

\section{FEM MODEL OF THE ELLIPSOIDAL HEAD WITH A NOZZLE}

\subsection{HEAD DESCRIPTION}

The ellipsoidal head of the radius $a$, depth $b$ and wall thickness $t_{e}$ is supported at the edge. The head is connected with a cylindrical central nozzle of diameter $c$ and wall thickness $t_{k}$. The distance between the edge of the head and the edge of the nozzle is constant and equals $d$. The nozzle is loaded with lengthwise force $F$ - tension or compression.

\subsection{FEM MODEL}

The ellipsoidal head and the nozzle are thin-walled shells of revolution; hence they are modeled with shell 181 elements - ANSYS system (Fig. 2). 


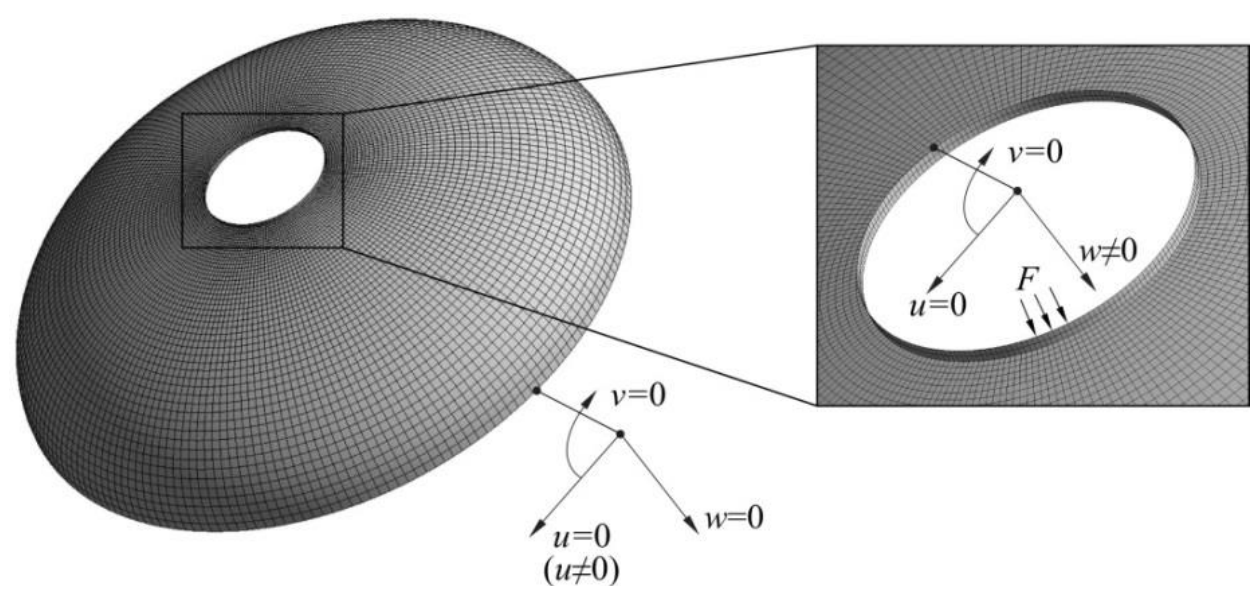

Fig. 2. Scheme of the ellipsoidal head with a nozzle

These elements have four nodes and six degrees of freedom in each node. The model of the head is defined in the cylindrical coordinate system. Conservative force is applied to the edge of the nozzle (total force spreads equally on all nodes). Two types of support conditions have been applied to the edge of the head. The first one is a simple support - the radial $u$, circumferential $v$ and axial $w$ displacements are blocked. In the second case the radial displacements $u$ are allowed. An additional support has been introduced to the edge of the nozzle: only axial displacements $w$ are allowed.

The mechanical properties of the material of the head assumed in analyses correspond to steel: Young's modulus $E=2 \cdot 10^{5} \mathrm{MPa}$, Poisson's ratio $v=0.3$. The nozzle has been modelled in a simplified way. By its shortening and stiffening (Young's modulus is $10^{3}$ times higher than the one for the material of the head) the influence of the length and deformation of the nozzle on the buckling behavior of the head has been eliminated. Since the present considerations are limited to the elastic buckling, plastic properties of the material have not been defined. The following geometrical parameters have been assumed (see Fig 1):

$a=750 \mathrm{~mm}, b=375 \mathrm{~mm}, d=425 \mathrm{~mm}, t_{e}=4 \mathrm{~mm}, t_{k}=6 \mathrm{~mm}$. The diameter of the nozzle varies in the range $c=<100,500>\mathrm{mm}$. 


\section{NUMERICAL ANALYSIS}

\subsection{CRITICAL LOADS - CRITICAL STATES}

The goal of the linear buckling analysis is to investigate the influence of the load - compression, tension - and the diameter of the nozzle on the buckling shape and buckling load of the head. The influence of different support conditions is also analyzed.

Examples of buckling modes are shown in Fig. 3. In the case of compressive force the buckling is related to the indentation and rotation of the nozzle (Fig. 3a, and 3b). For the tensile force a number of short circumferential waves appear around the nozzle in the region of the highest compressive stress (Fig. 3c).

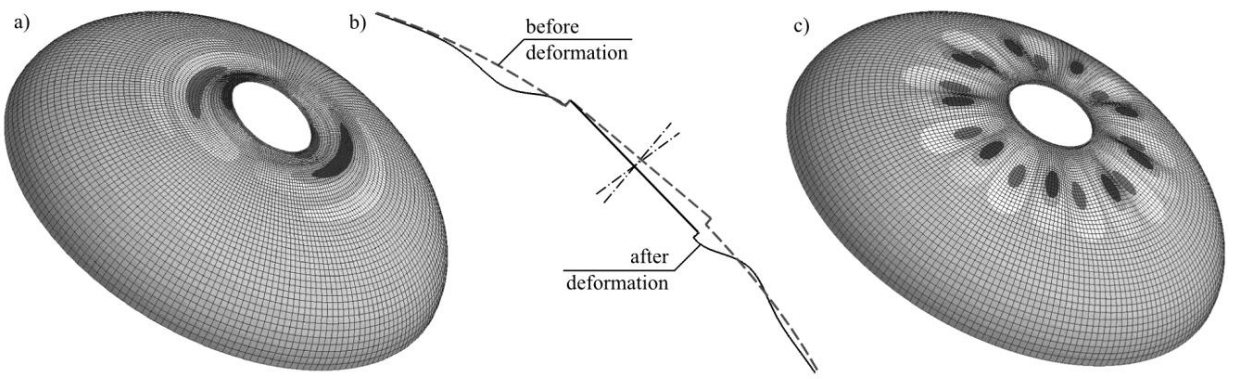

Fig. 3. First buckling mode of the ellipsoidal head: under compression a), b); under tension c)

The influence of the nozzle diameter on the value of the critical load of the head is shown in Fig. 4. On the horizontal axis the diameter of the nozzle $c$ is given.

The vertical axis corresponds to the dimensionless critical force which is the ratio of the critical force for a given case $\left(F_{c r}\right)$ and the critical load corresponding to the case of ellipsoidal head without nozzle $(c=0 \mathrm{~mm})\left(F_{c r}{ }^{c=0}\right)$. However to avoid numerical errors and to assure the axially symmetrical mesh a very small nozzle has been modelled, namely $c=10 \mathrm{~mm}$. 


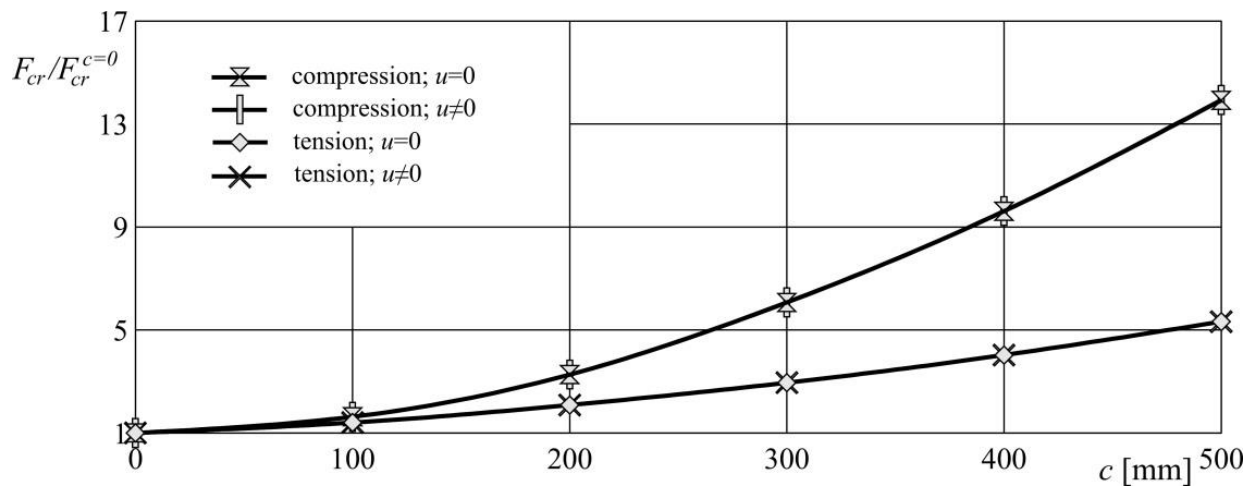

Fig. 4. Influence of a nozzle diameter on the critical load of a head

In both load cases the increase of the diameter of the nozzle results in the increase of the critical load. This increase is much higher for the compressive forces $-1600 \%$ for the case of $c=500 \mathrm{~mm}$ when compare to the fully ellipsoidal head. In the case of tension the increase equals about $500 \%$. The change of support conditions does not influence the results. The curves in Fig. 4 overlap each other for both cases considered $-u=0$ and $u \neq 0$. For that reason the post-critical investigation is limited to the case of $u=0$.

\subsection{EQUILIBRIUM PATHS - POST-CRITICAL STATES}

Nonlinear post-buckling analysis has been performed to determine the post-critical behavior of the ellipsoidal head. The results are given in Fig. 5 in the form of equilibrium paths. The horizontal axis corresponds to the maximum deflection reported during the analysis normalized by the thickness of the head. The value of applied load divided by the critical load is shown on the vertical axis. The ordinate equal to 1.0 corresponds to the linear buckling load. The geometrical imperfections have been introduced into the model in the form of the first buckling mode. The magnitude of these imperfections equals $1 \%$ of the thickness of the head $\left(0.01 t_{e}\right)$.

In the case of compression (Fig. 5a) the equilibrium path has an unstable character - after reaching the maximum value the load decreases while the deformation increases rapidly. For all considered values of $c$ the maximum load reported in the analysis is below $50 \%$ of the critical load estimated in the buckling analysis. 

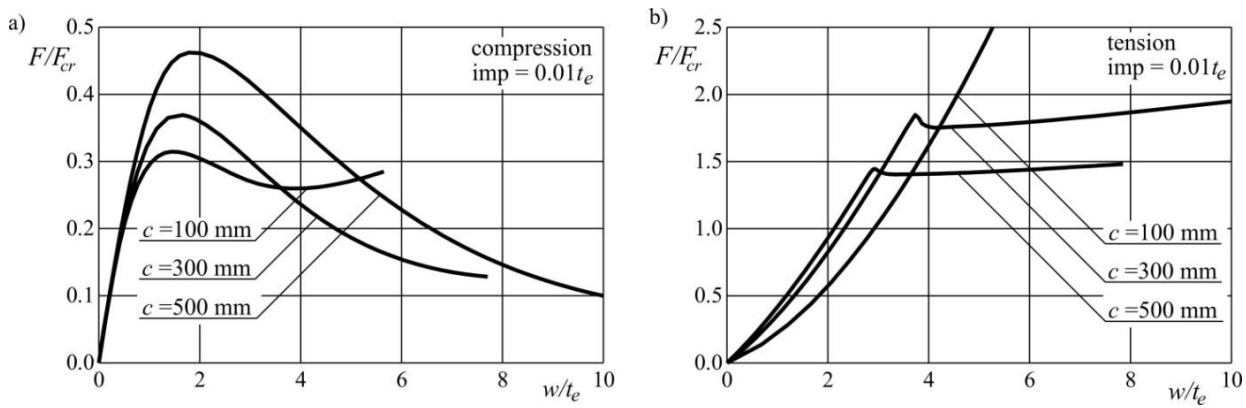

Fig. 5. Equilibrium paths for the ellipsoidal head with the different nozzle diameter

The smallest value corresponds to $c=100 \mathrm{~mm}$ end equals $0.31 F_{c r}$. As to the difference between the upper and lower critical load (the latter is understood as the minimum on the curve, after the upper critical load is exceeded) is the smallest also for $c=100 \mathrm{~mm}$. The higher the diameter of the nozzle, the higher the difference between the upper and lower critical load.

When the tensile load is applied the head behaves in a stable way and the load increases monotonically far above the critical load. The flattening of the equilibrium path that can be observed for the parameter $c=300$ and $500 \mathrm{~mm}$ is related to the rapidly growing indentations in the form of a buckling shape.

For the nozzle of the diameter of $c=300 \mathrm{~mm}$ an additional non-linear analysis has been performed to investigate the influence of the magnitude of initial geometrical imperfections on the post-critical behavior of the head. Three different values of imperfections have been considered that is 1 , 50 and $100 \%$ of the head thickness. The results are shown in Fig. 6.
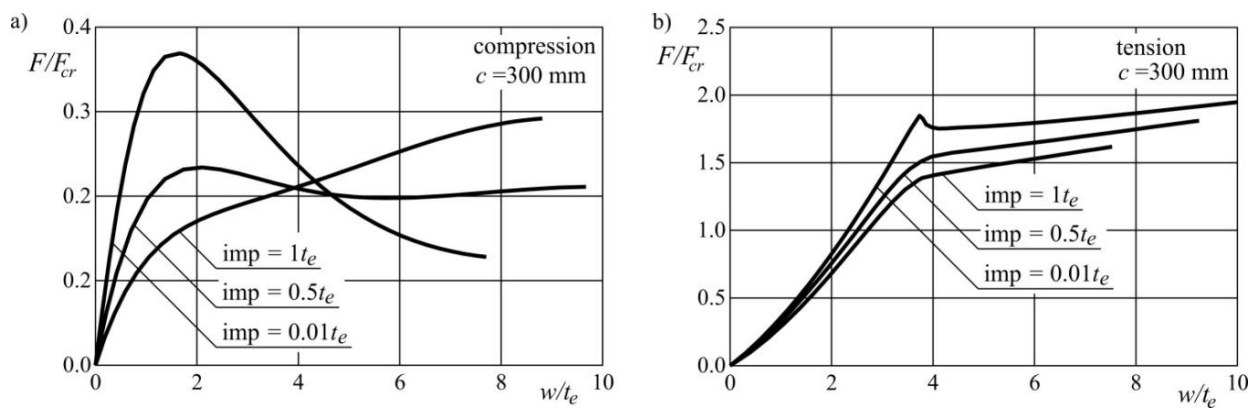

Fig. 6. Influence of the magnitude of imperfections on the post-critical behavior of the ellipsoidal head 
For the compressive force a higher magnitude of imperfections result in a further decrease of the upper critical load. In the case of tensile force the equilibrium path looks very similar for all considered imperfections - all paths are stable and the flat region appears above the critical load.

\section{ConClusions}

The present work is devoted to the numerical analysis of the critical and post-critical states of the ellipsoidal head with a nozzle. The influence of the diameter of the nozzle on the buckling shape and the buckling load has been analyzed for two cases of loads - compression and tension. Moreover a selected head has been investigated for the post-critical behavior.

The results of the linear analysis show that the diameter of the nozzle does not influence the buckling shape but it has considerable influence on the buckling load in both load cases. The support conditions at the edge of the head have no influence on the buckling behavior.

The non-linear post-buckling analysis shows that under compressive load the behavior of the head in the post-critical range is unstable.

Moreover even small initial imperfections reduce the load capacity of the analyzed heads to below $50 \%$ of the critical load obtained in the linear buckling analysis. This reduction is the highest for the smallest diameter of the nozzle. However, in this case the difference between the upper and lower critical load is the smallest what suggest that heads with smaller nozzles behave more stable in the post-critical range.

In the case of the tension load, the head behaves stable even far above the buckling load for all cases considered. The size of the initial geometrical imperfections does not influence this behavior.

\section{ACKNOWLEDGEMENTS}

The presented research results, executed under the subject of No $02 / 21 / \mathrm{DSPB} / 3452$, were funded by educational grants allocated by the Ministry of Science and Higher Education. 


\section{REFERENCES}

1. J. Błachut, K. Magnucki, Strength, stability, and optimization of pressure vessels: Review of selected problems, Applied Mechanics Reviews, 61, 6, No 060801, 2008.

2. A. Yu. Evkin, Large deflections of deep orthotropic spherical shells under radial concentrated load: asymptotic solution, International Journal of Solids and Structures, 42, 1173-1186, 2005.

3. D. Bushnell, Computerized buckling analysis of shells, Kluwer Academic Publishers, Dordrecht, Boston, London 1989.

4. J. R. Fitch, The buckling and post-buckling behavior of spherical caps under concentrated load, International Journal of Solids and Structures, 4, 4, 421-446, 1968.

5. Э. И. Григолюк, В. В. Кабанов, Устойчивость оболочек, «Наука〉 Москва 1978.

6. N. K. Gupta, G. L. E. Prasad, S. K. Gupta, Axial compression of metallic spherical shells between rigid plates, Thin-Walled Structures, 34, 21-41, 1999.

7. P. Jasion, Stability analysis of shells of revolution under pressure conditions, Thin-Walled Structures, 47, 311-317, 2009.

8. S. N. Krivoshapko, Research on general and axisymmetric ellipsoidal shells used as domes, pressure vessels, and tanks, Applied Mechanics Reviews, 60, 6, 336-355, 2007.

9. J. M. T. Thompson, G. W. Hunt, A general theory of elastic stability, John Wiley \& Sons, London 1973.

10. P. E. Tovstik, A. L. Smirnov, Asymptotic methods in the buckling theory of elastic shells, World Scientific Publishing, Singapore 2001.

11. J. Ziółko, Zbiorniki metalowe na ciecze i gazy, Wydawnictwo Arkady, Warszawa 1986.

\section{LIST OF FIGURES AND TABLES:}

Fig. 1. Scheme of the ellipsoidal head with a nozzle

Rys. 1. Geometria dna elipsoidalnego z króćcem

Fig. 2. FE model of the head

Rys. 2. Model MES dna

Fig. 3. First buckling mode of the ellipsoidal head: under compression a), b); under tension c)

Rys. 3. Pierwsza postać wyboczenia dna elipsoidalnego: ściskanego a), b); rozciąganego c)

Fig. 4. Influence of a nozzle diameter on the critical load of a head

Rys. 4. Wpływ średnicy króćca na wartość obciążenia krytycznego dna

Fig. 5. Equilibrium paths for the ellipsoidal head with the different nozzle diameter

Rys. 5. Ścieżki równowagi dna elipsoidalnego z króćcami o różnych średnicach

Fig. 6. Influence of the magnitude of imperfections on the post-critical behavior of the ellipsoidal head

Rys. 6. Wpływ wielkości imperfekcji na pokrytyczne zachowanie dna elipsoidalnego 


\section{STATECZNOŚĆ DNA ELIPSOIDALNEGO Z KRÓĆCEM ŚRODKOWYM POD OBCIĄŻENIEM OSIOWYM}

Slowa kluczowe: dno elipsoidalne, stateczność, wyboczenie, zbiornik ciśnieniowy

\section{STRESZCZENIE:}

Praca poświęcona jest analizie stateczności dna elipsoidalnego będącego typowym elementem zbiorników ciśnieniowych. Dno zakończone jest króćcem obciążonym siłą osiową ściskającą lub rozciągającą. Przeanalizowano wpływ średnicy króćca na wartość obciążenia krytycznego, postać wyboczenia oraz na przebieg ścieżki równowagi dna.

Wszystkie analizy przeprowadzono metodą elementów skończonych (MES) w systemie ANSYS. Dno, będące powłoką obrotową, zamodelowano elementami powłokowymi typu shell 181. Są to elementy liniowe, czterowęzłowe z sześcioma stopniami swobody w każdym węźle. Model dna zdefiniowano w cylindrycznym układzie współrzędnych. Obciążenie, o charakterze konserwatywnym, przyłożono do krawędzi króćca. Rozpatrzono dwa przypadki podparcia. W pierwszym przypadku na krawędzi dna odebrano wszystkie możliwości przemieszczeń. W przypadku drugim odebrano możliwość przemieszczeń w kierunku osiowym i obwodowym; możliwe jest przemieszczenie promieniowe. Dodatkowo, w obu rozpatrywanych przypadkach obciążeń, zablokowano możliwość przemieszczeń obwodowych i promieniowych na krawędzi króćca.

Własności mechaniczne modelu materiału wykorzystanego do analizy odpowiadają stali: moduł Younga $E=2 \cdot 10^{5} \mathrm{MPa}$, współczynnik Poissona $v=0,3$. Aby wyeliminować wpływ deformacji króćca na zachowanie się dna został on zamodelowany w sposób uproszczony. Króciec został maksymalnie skrócony, a moduł Younga materiału, który posłużył do jego zamodelowania, jest $10^{3}$ razy większy, niż moduł materiału dna. Analiza została ograniczona do wyboczenia sprężystego. W związku z tym modele materiałów użytych w analizie są liniowo-sprężyste.

Pierwszym etapem badań było przeprowadzenie liniowej analizy stateczności den, w której zbadano wpływ średnicy króćca na wartość obciążenia krytycznego i postać wyboczenia dna. Zbadano również wpływ warunków podparcia.

W przypadku siły ściskającej w momencie wyboczenia następuje wciśnięcie króćca do wewnątrz dna i obrót. Postać wyboczenia dla siły rozciągające ma kształt drobnych fal obwodowych rozmieszczonych równomiernie wokół króćca, w obszarze największych naprężeń ściskających. W obu przypadkach obciążenia zwiększanie średnicy króćca powodowało zwiększenie wartości obciążenia krytycznego. Wzrost ten jest znacznie większy przy ściskaniu dna niż przy jego rozciąganiu. Sposób podparcia nie miał wpływu ani na postać wyboczenia ani na wartość obciążenia krytycznego.

Drugi etap badań polegał na wyznaczeniu ścieżek równowagi dla wybranych den w celu sprawdzenia charakteru zachowania pokrytycznego. Ponieważ w poprzednim kroku badań wykazano brak wpływu warunków podparcia na wyniki analizy, wybrano tylko jeden sposób podparcia - zablokowano wszystkie przemieszczenia na krawędzi dna. 
Nieliniową geometrycznie analizę przeprowadzono przy pomocy metody łuku. Do modelu wprowadzono niedoskonałości geometryczne, imperfekcje, których kształt odpowiada pierwszej postaci wyboczenia otrzymanej w analizie liniowej. Wielkość imperfekcji jest równa 1\% grubości dna.

Przy obciążeniu ściskającym ścieżki równowagi mają charakter niestabilny. Oznacza to, że po osiągnięciu maksymalnego obciążenia ugięcie zaczyna gwałtownie narastać a siła obciążająca maleje. Dla wszystkich rozpatrywanych średnic króćca wartość maksymalnego obciążenia uzyskanego w analizie nieliniowej jest co najmniej 50\% mniejsza niż ta, otrzymana w analizie liniowej - im mniejsza średnica króćca, tym większa różnica między wartościami uzyskanymi w analizie liniowej i nieliniowej. Ponadto im większa średnica króćca tym większa różnica między maksymalnym i minimalnym obciążeniem na ścieżce równowagi.

W przypadku obciążenia rozciągającego dno zachowuje się w sposób stabilny - obciążenie wzrasta monotonicznie powyżej obciążenia krytycznego. Płaskie fragmenty ścieżek równowagi odpowiadają szybkiemu wzrostowi amplitudy fal powstałych w momencie utraty stateczności.

Dla wybranej wartości średnicy króćca przeprowadzono dodatkową analizę nieliniową pokazującą wpływ wielkości imperfekcji geometrycznych na przebieg ścieżki równowagi. Trzy rozpatrzone wielkości imperfekcji to 1,50 i $100 \%$ grubości dna. W przypadku obciążenia ściskającego wzrost imperfekcji powoduje szybki spadek maksymalnego obciążenia; charakter ścieżki pozostaje niestabilny. Natomiast w przypadku rozciągania przebieg ścieżki równowagi zmienia się nieznacznie. Również jej charakter pozostaje stabilny. 